\title{
The prostaglandin $\mathrm{F}$ synthase activity of the human aldose reductase AKR1B1 brings new lenses to look at pathologic conditions
}

\section{Eva Bresson, Nicolas Lacroix-Pépin, Sofia Boucher-Kovalik, Pierre Chapdelaine and Michel A. Fortier*}

Unité de Recherche en Ontogénie et Reproduction, Centre Hospitalier Universitaire de Québec, Centre de Recherche en Biologie de la Reproduction, Département d'Obstétrique et Gynécologie, Université Laval, Ste-Foy, QC, Canada

Edited by:

Yi Jin, University of Pennsy/vania, USA

Reviewed by:

Michael Curtis Byrns, Illinois State University, USA

Antoine Martinez, Centre National de la Recherche Scientifique, France

\section{*Correspondence:}

Michel A. Fortier, Axe Reproduction, santé de la mère et de l'enfant. Centre Hospitalier Universitaire de Québec, Université Laval, 2705 boulevard Laurier, Ste-Foy, QC,

Canada G1V 4G2.

e-mail:mafortier@crchul.ulaval.ca
Prostaglandins are important regulators of female reproductive functions to which aldose reductases exhibiting hydroxysteroid dehydrogenase activity also contribute. Our work on the regulation of reproductive function by prostaglandins (PGs), lead us to the discovery that AKR1B5 and later AKR1B1 were highly efficient and physiologically relevant PGF synthases. PGE2 and PGF2 $\alpha$ are the main prostanoids produced in the human endometrium and proper balance in their relative production is important for normal menstruation and optimal fertility. Recent evidence suggests that PGE2/EP2 and PGF2 $\alpha / F P$ may constitute a functional dyad with physiological relevance comparable to the prostacyclin-thromboxane dyad in the vascular system. We have recently reported that AKR1B1 was expressed and modulated in association with PGF2 $\alpha$ production in response to IL-1 $\beta$ in the human endometrium. In the present study, we show that the human AKR1B1 (gene ID: 231) also known as ALDR1 or ALR2 is a functional PGF2 $\alpha$ synthase in different models of living cells and tissues. Using human endometrial cells, prostate, and vascular smooth muscle cells, cardiomyocytes and endothelial cells we demonstrate that IL-1 $\beta$ is able to up regulate COX-2 and AKR1B1 proteins as well as PGF2 $\alpha$ production under normal glucose concentrations. We show that the promoter activity of AKR1B1 gene is increased by IL-1 $\beta$ particularly around the multiple stress response region containing two putative antioxidant response elements adjacent to TonE and AP1. We also show that AKR1B1 is able to regulate PGE2 production through PGF2 $\alpha$ acting on its FP receptor and that aldose reductase inhibitors like alrestatin, Statil (ponalrestat), and EBPC exhibit distinct and characteristic inhibition of PGF2 $\alpha$ production in different cell models. The PGF synthase activity of AKR1B1 represents a new and important target to regulate ischemic and inflammatory responses associated with several human pathologies.

Keywords: prostaglandins, biosynthesis, regulation, endometrium, menstrual cycle

\section{INTRODUCTION}

The human aldose reductase ALR2 gene AKR1B1 is a notorious enzyme which has been associated with complications of diabetes for more than four decades (Srivastava et al., 2005). AKR1B1 is considered as the rate limiting enzyme of the polyol pathway responsible for the conversion of glucose into sorbitol. The association of AKR1B1 with cardiovascular risks, neuropathies, and nephropathies characteristic of diabetes is receiving increased acceptance (Alexiou et al., 2009). However, the contribution of the polyol pathway to the same complications is less convincing (Del Corso et al., 2008). Indeed, while many factors including inflammation induce increased expression and activity of AKR1B1, this enzyme has very little affinity for glucose at physiological concentrations and a detoxification action involving reduction of lipid peroxides has been proposed (Srivastava et al., 2005). While searching for the enzyme responsible for the production of PGF2 $\alpha$ in the endometrium, we made the serendipitous and unexpected discovery that AKR1B5 (Madore et al., 2003) and later the human aldose reductase AKR1B1 (Bresson et al., 2011) were highly functional PGFS. Prostaglandins (PGs) are notorious mediators of pain and inflammation also associated with proliferation of cancer cells. While the same mediators are recognized as primary regulators of female reproductive function (ovulation, uterine receptivity, implantation, and parturition) they also contribute to occurrence of endometrial carcinomas, menorrhagia, dysmenorrhea, endometriosis, and premature labor. Among the different PGs, PGE2 and PGF2 $\alpha$ are the main prostanoids produced in the human endometrium (Smith and Kelly, 1988; Sales and Jabbour, 2003a). PGs are synthesized from arachidonic acid (AA) and converted to $\mathrm{PGG}_{2}$ and $\mathrm{PGH}_{2}$ by $\mathrm{PGH}$ synthases (PGHS), also known as cyclooxygenases (COX). There are two documented isoforms of PGHS in human, the constitutive COX-1 and the inducible COX-2 encoded by two distinct genes (Smith et al., 1996). $\mathrm{PGH}_{2}$ produced by COXs is the common precursor of all PGs generated by specific terminal synthases such as PGF synthase for PGF2 $\alpha$ and PGE synthase for PGE2. The human terminal synthases responsible 
for the biosynthesis of PGE2 (Park et al., 2006), PGD2 (Zhou et al., 2010), and PGI2 (Wu and Liou, 2005) are well characterized, but only little is known for the enzyme responsible for PGF2 $\alpha$ production. Before our identification of the PGF synthase activity of aldo-ketoreductases (AKR) of the 1B family (Madore et al., 2003; Bresson et al., 2011) only one AKR of the 1C family, AKR1C3 was recognized as a functional PGF synthase in the human (Suzuki-Yamamoto et al., 1999).

PGF2 $\alpha$ is a biologically active prostanoid belonging to the eicosanoid family of bioactive lipids (Narumiya and FitzGerald, 2001). Its biosynthesis occurs via different pathways involving reduction of PGH2 by a 9,11-endoperoxyde reductase (Watanabe, 2002). Several PGFS have been identified in animals (Madore et al., 2003), but until recently, AKR1C3 was the only isoform currently identified in human (Komoto et al., 2006). In the bovine endometrium, using a cell-free system, we have demonstrated a strong PGFS activity of purified recombinant AKR1B5 recently renamed as bos taurus AKR1B1 (Gene ID: 317748) as well as circumstantial association between its pattern of expression and PGF2 $\alpha$ production. This represents a new putative function for this enzyme previously known for its $20 \alpha$-HSD and glucose metabolism activities (Madore et al., 2003). The human and bovine AKR1B1 (EC:1.1.1.21) both belong to the AKR1B family and share $86 \%$ identity or homology. The human AKR1B1 (Gene ID: 231) also known as the aldose reductase or ALDR1belongs to the AKR superfamily composed of 140 members divided into 15 families (Jin and Penning, 2007). AKR1B1 (EC:1.1.1.21) is primarily known as the rate limiting enzyme for conversion of glucose to sorbitol in the polyol pathway, but recent studies revealed its ability to convert a wide array of substrates including aldehydes generated during lipid peroxidation and their glutathione (GSH) conjugates, phospholipids, atherogenic lipids, and steroids (Srivastava et al., 2005).

After identifying the bovine AKR1B1 as a potential PGFS (Madore et al., 2003), we have shown circumstantial association with PGF2 $\alpha$ production in human endometrial cell lines (Chapdelaine et al., 2006) and in decidualized stromal cells (Kang et al., 2006). Later, the PGFS activity of mouse AKR1B3 and AKR1B7 as well as the human AKR1B1 were tested and confirmed using purified recombinant proteins in a cell-free system in vitro (Kabututu et al., 2009). Using a similar approach complemented with gain and loss of function in endometrial cell lines, we have demonstrated that the AKR1B1 was a functional PGFs in the human endometrium (Bresson et al., 2011). In the present study, we have investigated further the regulation of PGF2 $\alpha$ production by different stimulators and inhibitors as well as the promoter cis-elements responsible for IL-1 $\beta$ response in human endometrial cell lines. Finally, we have studied the association between AKR1B1 and PGF2 $\alpha$ production in representative tissues where PGF2 $\alpha$ was found to exert physiological action in vivo. We have evaluated the potential of different AKR1B1 inhibitors (ARI) to alter PGs production in living cells and in fresh endometrial tissues under normal and high glucose conditions.

\section{MATERIALS AND METHODS REAGENTS}

RPMI 1640 culture medium without phenol, Superscript II reverse transcriptase, TRIzol, lipofectamine 2000, and pCR3.1 vectors were purchased from Invitrogen (Life technologies, ON, Canada). TAQ DNA polymerase and buffer used for polymerase chain reaction were from NEB (New England Biolabs, ON, Canada). RiboMax polymerase kit for siRNAs was purchased from Promega (Madison, WI, USA). Qiaquick gel extraction kit and TA cloning pDrive vector were from Qiagen (Mississauga, ON, Canada). All oligonucleotide primers were chemically synthesized by Integrated DNA Technologies (IDT) (Coralville, IA, USA). $\left[\alpha-{ }^{32} \mathrm{P}\right] \mathrm{dCTP}$ radioactivity was bought from PerkinElmer Life Sciences (Markham, ON, Canada). Bright Star-Plus nylon membrane and UltraHyb solution were purchased from Ambion Inc. (Austin, TX, USA). The rabbit COXs antibodies were kindly provided by Dr S Kargman (Merck, QC, Canada), rabbit anti-Phospho$\mathrm{CPLA}_{2}$ (Ser505) was from Santa Cruz biotechnology (Santa Cruz, CA, USA) and AKR1C3 was from Abcam Inc. (Cambridge, MA, USA). Goat anti-rabbit horse-radish peroxidase-conjugated IgG was bought from Jackson Immunoresearch Laboratories (West Grove, PA, USA). The Western Lightning ${ }^{\mathrm{TM}}$ Chemiluminescence Reagent Plus was purchased from PerkinElmer (Woodbridge, ON, Canada). Arachidonic acid (AA), and AL-8810 were from Cayman Chemicals (Ann Arbor, MI, USA) and recombinant human IL- $1 \beta$ was purchased from Research and Diagnostic Systems (Minneapolis, MN, USA). Aldose reductase inhibitors (ARIs), [ponalrestat (Statil), Alrestatin, and EBPC] were from Tocris Bioscience (Ellisville, MO, USA).

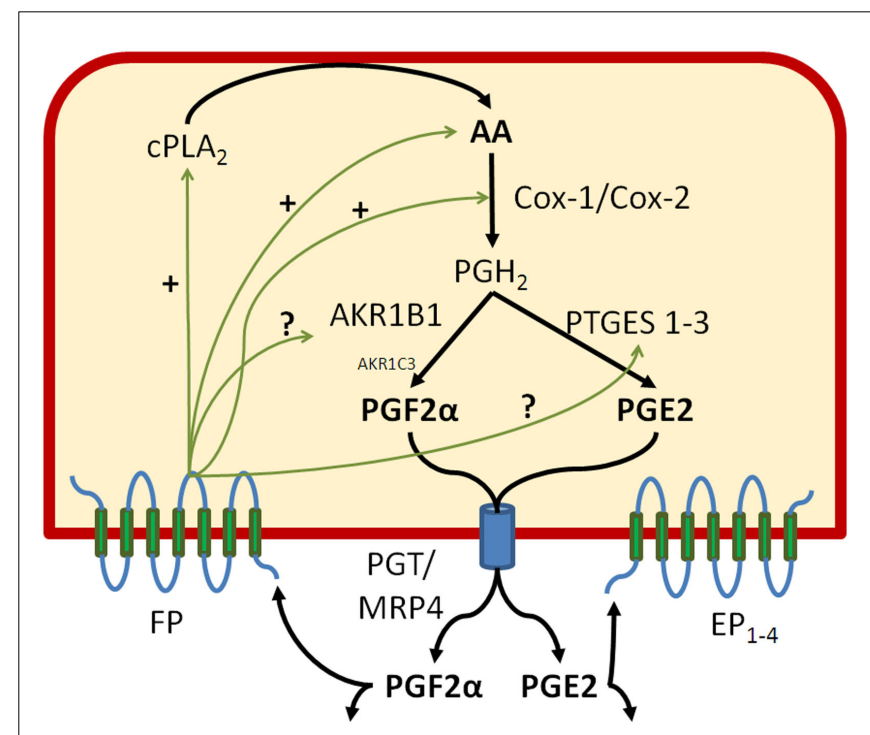

FIGURE 1 | Prostaglandin F2 $\alpha$ and E2 biosynthetic pathways. In order to generate PGF2 $\alpha$, AKR1B1 must team up with other constitutive and inducible enzymes involved in the production of $\mathrm{PGH} 2$, the common precursor of all PGs. Among those, we have found that CPLA2 liberating AA from membrane phospholipids, COX-2, AKR1B1, and mPGES-1 are inducible by the cytokine IL-1 $\beta$. AKR1B1 apparently works with both COX-1 and COX-2 producing PGH2 to generate PGF2 $\alpha$ whereas mPGES-1 preferentially associates with COX-2 to generate PGE2. Both epithelial and stromal cells exhibit PGF2 $\alpha$ responsiveness and stimulation or inhibition of the FP receptor alters the production of both PGE2 and PGF2 $\alpha$ through action at several steps of the PG biosynthesis cascade. We also present in this figure the PG transporters PGT also known as solute carrier SLCOA1 and MRP4 the multidrug resistance protein 4 or ABCC4. 
A

\section{HIESC-2}

$\begin{array}{llll}1 & 2 & 3 & 4\end{array}$
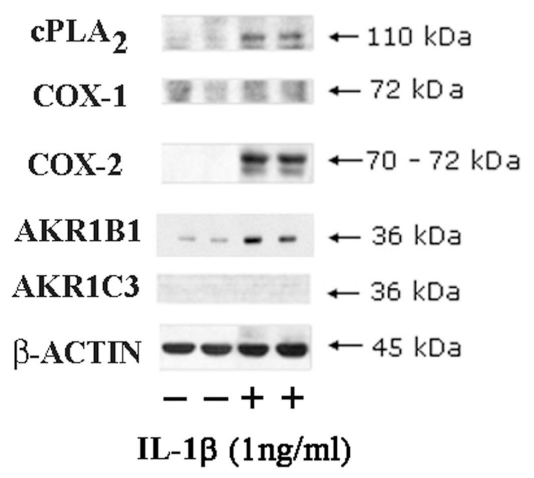

C

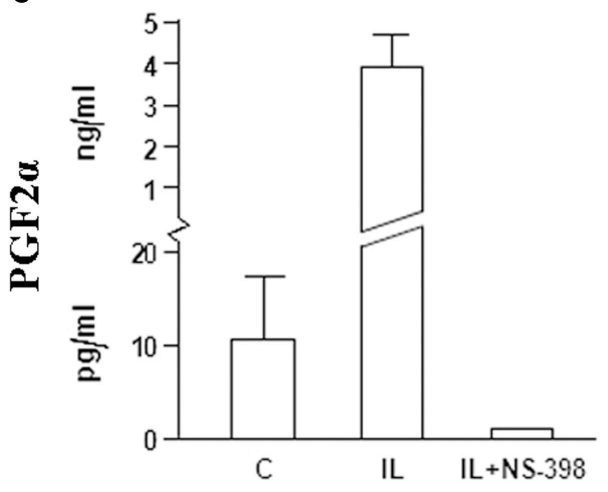

B

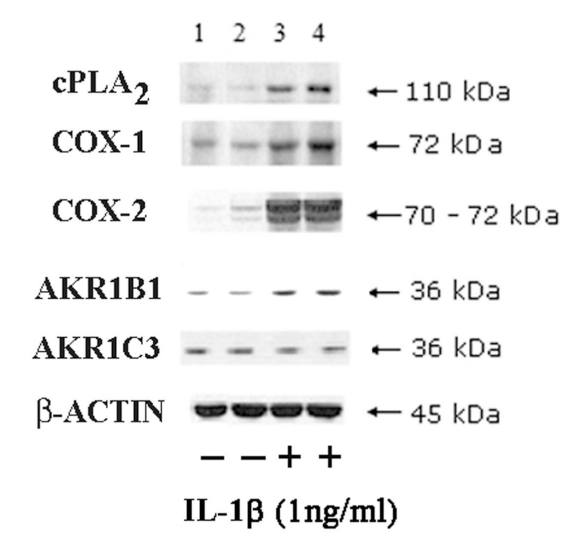

D

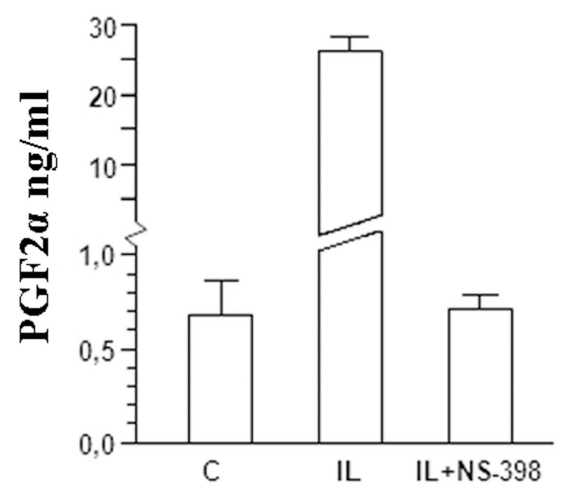

FIGURE 2 | Influence of IL-1 $\beta$ on the main biosynthetic enzymes associated with PGF2 $\alpha$ production in human endometrial stromal and epithelial cells. Human endometrial stromal (HIESC-2) and epithelial (HIEEC-2) cells were grown to confluence and treated with

\section{CULTURED CELL MODELS}

Human endometrial stromal (HIESC-2) and epithelial (HIEEC22) cell lines were immortalized using SV40 large $T$ antigen (Chapdelaine et al., 2006) and shown to exhibit most characteristics of freshly isolated endometrial cells (Kang et al., 2004, 2006). Bovine endometrial epithelial cells were immortalized using a similar protocol and also presented most characteristics of freshly isolated cells (Krishnaswamy et al., 2009, 2010; Lacroix-Pepin et al., 2011). Human prostate smooth muscle cells, human artery smooth muscle cells, human umbilical vein endothelial cells (Huvec), and human cardiomyocytes cells were from ScienCell Research Laboratories (Carlsbad, CA, USA).

\section{NORTHERN BLOT}

Northern blot analysis was performed as follows: total RNA ( $\sim 20 \mu \mathrm{g}$ ) was extracted with Trizol (Invitrogen, Life technologies, ON, Canada) from cultured endometrial cells, loaded on a $1.2 \%$ formaldehyde-agarose gel and electrophoresed at $100 \mathrm{~V}$ in $1 \times$ MOPS buffer. After electrophoresis, RNA was transferred overnight onto a nylon membrane in $10 \times$ saline-sodium citrate (SSC). The AKR1B1, mPGES-1, COX-1, and COX-2 cDNA probes were produced by digestion with restriction enzymes of different plasmids containing the corresponding cDNAs previously generated in our laboratory, each releasing a $\sim 500 \mathrm{bp}$ fragment. The resulting probes were labeled with $\left[\alpha-{ }^{32} \mathrm{P}(\mathrm{dCTP}\right.$ $(3000 \mathrm{Ci} / \mathrm{mmol})$ using the Ready-To-Go DNA labeling Kit (GE Healthcare Life Science, QC, Canada). Prehybridization (2-4 h) and hybridization (overnight) were done at $45^{\circ} \mathrm{C}$ using UltraHyb solution (Ambion Inc., Invitrogen, Life technologies, ON, Canada). The blots were then washed at $65^{\circ} \mathrm{C}$ twice for $15 \mathrm{~min}$ in $0.5 \times \mathrm{SSC}$ and exposed for $24-48 \mathrm{~h}$ at $-80^{\circ} \mathrm{C}$ on BioMAx films PerkinElmer (Woodbridge, ON, Canada) to quantify the hybridization signal intensity. Finally, $18 \mathrm{~S}$ ribosomal RNA stained with ethidium bromide was used to confirm uniform loading of RNA samples and a 32P-labeled oligonucleotide specific to $18 \mathrm{~S}$ ribosomal RNA was used as an internal standard for Northern blot analysis.

\section{WESTERN BLOT}

Western blot analysis was performed as we described (Chapdelaine et al., 2006). Briefly, total proteins ( $20 \mu \mathrm{g})$ extracted from culture cells were loaded in each lane and electrophoresis done on $10 \%$ SDS-PAGE followed by electrotransfer onto nitrocellulose membrane (Bio-Rad laboratories, Mississauga, ON, Canada). The 

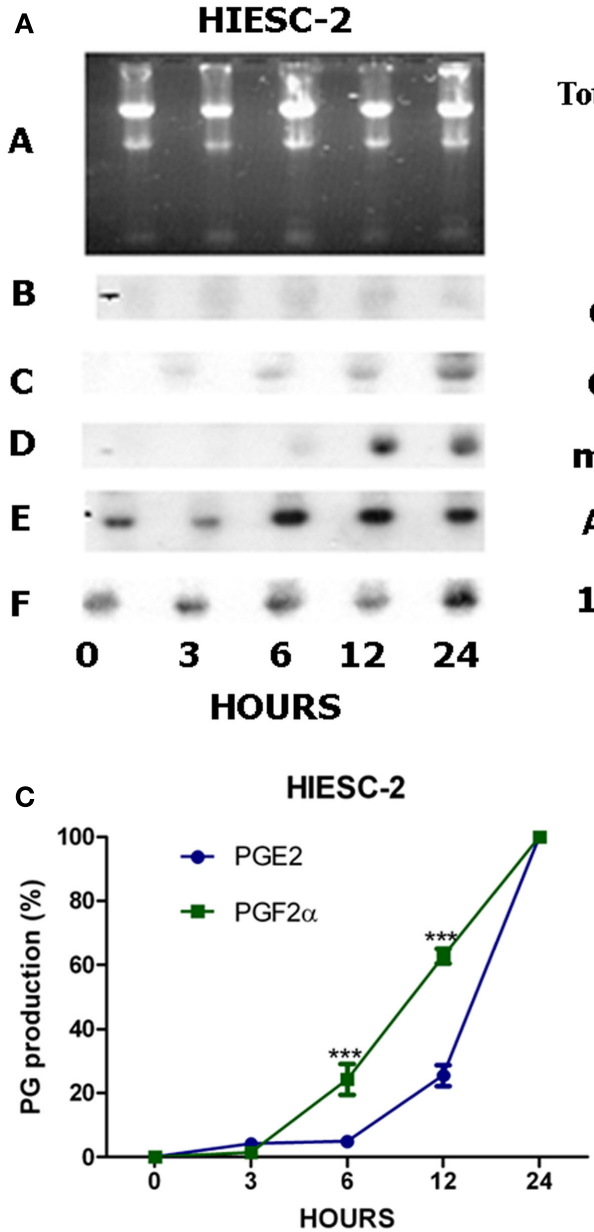

FIGURE 3 |Time course of gene expression and PGs production in human endometrial stromal and epithelial cells following stimulation with IL-1 $\beta$. Human endometrial stromal (HIESC-2) and epithelial (HIEEC-2) cells were grown to confluence and treated with IL-1 $\beta$ for different periods up
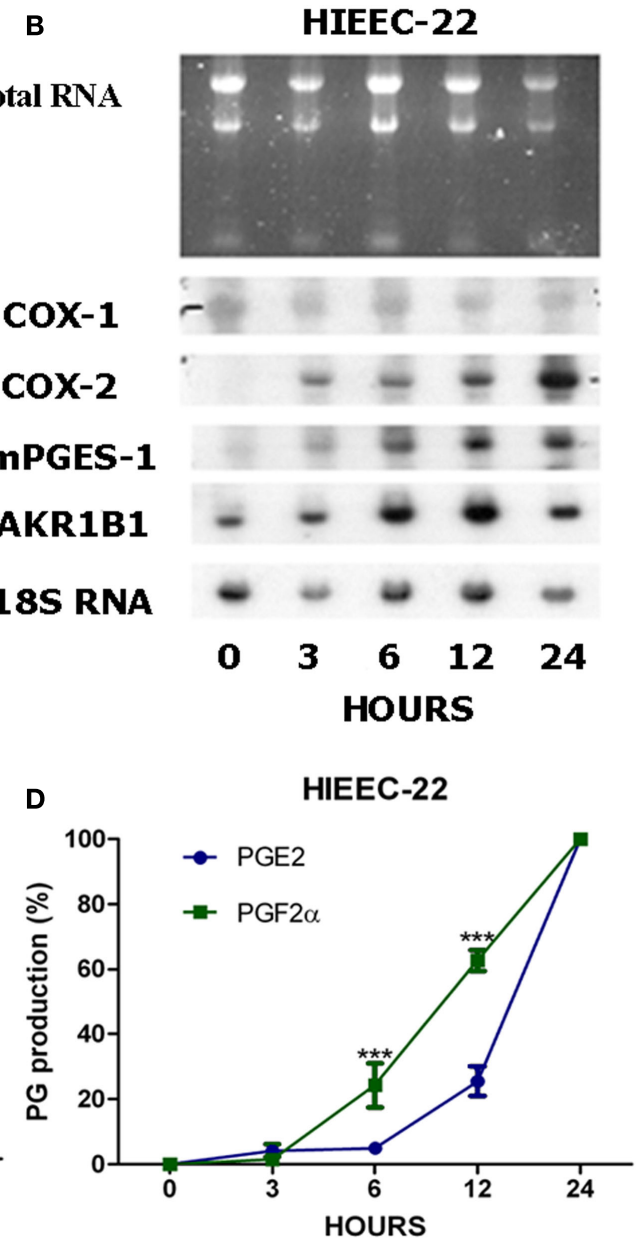

to $24 \mathrm{~h}$. Northern Blots analysis $(\mathbf{A}, \mathbf{B})$ was used for detection of AKR1B1, COX-1/-2, mPGES-1 mRNAs expression. The production of PGs was evaluated as a function of time in stromal (C) and epithelial (D) endometrial cells where stimulation ofPGF2 $\alpha$ precedes that of PGE2 $(P<0.05)$. primary antibodies used for the present study were the rabbit AKR1B1 (dilution 1/1000), COX-1 or COX-2 (dilution 1/3000), cPLA2 (1/1000) and goat AKR1C3 (1/500) anti-serums. As an internal control, the $\beta$-actin monoclonal antibody (1/5000, Sigma, Mississauga, ON, Canada) was used. The goat anti-rabbit IgG conjugated with horse radish peroxidase (HRP), rabbit anti-goat IgG HRP or goat anti-mouse IgG HRP were used as secondary antibodies. The chemiluminescence was analyzed with autoradiography films at optimal times of exposure following treatment of the membranes with the Western Lightning ${ }^{\mathrm{TM}}$ Chemiluminescence Reagent Plus (PerkinElmer Canada).

\section{ANALYSIS OF AKR1B1 PROMOTER ACTIVITY}

A nested PCR strategy was developed to generate a long $\sim 4.5 \mathrm{~kb}$ promoter to study the regulation of the AKR1B1 gene (AF032455). The promoter PCR fragments were amplified with PFU turbo DNA polymerase (Stratagene, Agilent technologies, USA) and cloned directly by fusion (Clontech, TAKARA Biocompany) in a pGL3 basic vector (Promega) containing the firefly luciferase gene.
Constructs of AKR1B1 promoter of seven different lengths were generated using restriction enzymes targeting unique sequences in the long promoter. A short portion of the AKR1B1 promoter corresponding to the multiple stress response region (MSRR) -1710 to -1064 to the translation initiation ATG position was amplified by PCR, cloned in a TA cloning vector (pDrive, Qiagen) for sequencing and linked in a pGL3 vector (Promega) to the minimal SV40 promoter. From this, additional constructs were produced by deletion of the cis-elements corresponding to TONE and AP1 or ARE1 and 2. Stromal (HIESC-2) and epithelial (HIEEC-22) cells were co-transfected with the lipofectamine 2000 transfection agent (Invitrogen) and the different plasmid constructs possessing the firefly luciferase reporter and a plasmid containing the synthetic Renilla luciferase gene. After transfection, cells were treated for $24 \mathrm{~h}$ with IL-1 $\beta$ ( $1 \mathrm{ng} / \mathrm{ml})$, and the promoter activity was expressed as the ratio of firefly luciferase to the renilla luciferase using the Dual-Luciferase Reporter (DLR $\left.{ }^{\mathrm{TM}}\right)$ Assay System (Promega, Madison, WI, USA) using a Luminoskan Ascent luminometer (ThermoElectron Corporation, Milford, MA, USA). 
A

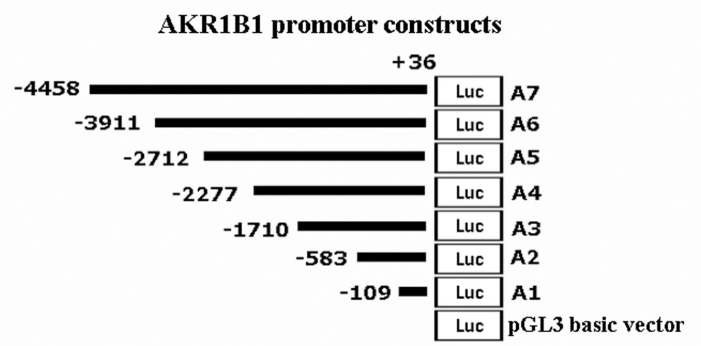

HIESC-2

HIEEC-22
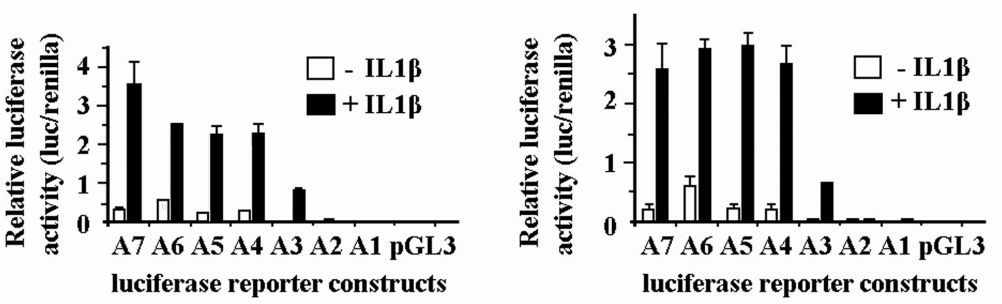

B

$\stackrel{-1710}{\operatorname{lgg}}$

MSRR (-1710 to -1064$)$

gggtcttgctatgttgtccaggctggt-----agcaccaaaTGGAAAATCACcggcat TonE (NFkB)

ggagtttagagagacctggtgctTGAGTCActaccaggcagatggagttcccaatctt

AP1

GCATATTAggggaaagatcggagggTGATGGAGCagaaagagcagttggggtga ARE 2

ARE 1

$-1064$

C
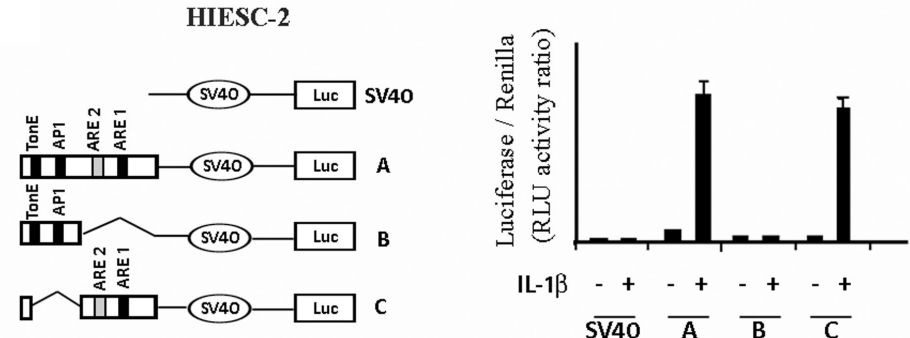

FIGURE 4 | Analysis of AKR1B1 promoter activity involved in IL-1 $\beta$ response in human endometrial cells. (A) Schematic representation of different AKR1B1 promoter constructs and corresponding activity following treatment of transfected stromal and epithelial cells treated with IL-1 $\beta$. (B) Nucleotide sequence of the AKR1B1 promoter MSRR

\section{CELL TREATMENTS}

HIESC-2 (passages 15-22) and HIEEC-22 (passages 15-22) were cultured in RPMI 1640 without phenol red, containing $50 \mathrm{IU}$ penicillin-streptomycin supplemented with $10 \%$ whole FBS during growth and 10\% dextran-coated charcoal extracted FBS once cells have reached confluence and for transfection or treatments.

region ( -1710 to -1064$)$ showing the organization of the important cis-elements TonE (NFKB), AP1 and anti-oxidant response elements 1 and 2 (ARE1 and ARE2). (C) Relative activity of MSRR cis-elements of the AKR1B1 promoter following stimulation with IL-1 $\beta$ of transfected stromal endometrial cells. 


\section{Prostatic Smooth Muscle cells}
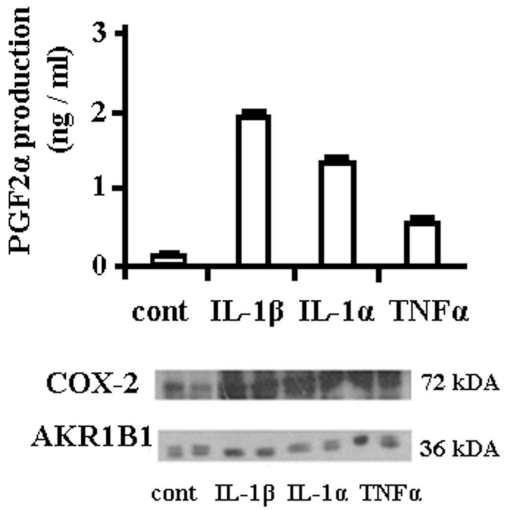

C

\section{Human Cardiomyocytes \\ treated with $\mathbb{L}-1 \beta$ and TNF $\alpha$}

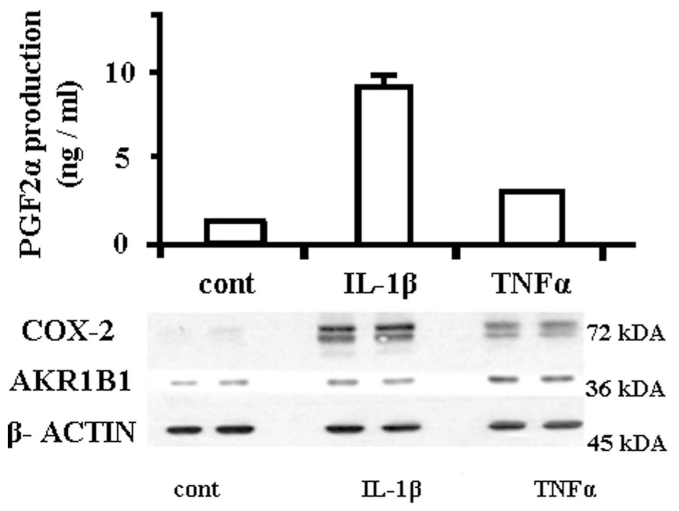

FIGURE 5 | Association between induction of AKR1B1 and PGF2 $\alpha$ production following cytokine stimulations in cells from different human tissues. Cells from different human tissues were grown to confluence and treated with IL-1 $\beta$ or IL- $1 \alpha 1 \mathrm{ng} / \mathrm{ml}$ or TNF $\alpha$ at $10 \mathrm{ng} / \mathrm{ml}$ for $24 \mathrm{~h}$. The culture medium was recovered for assay of
B

\section{Human Artery Umbilical Smooth Muscle cells (HUASMC) treated with IL-1 $\beta$}

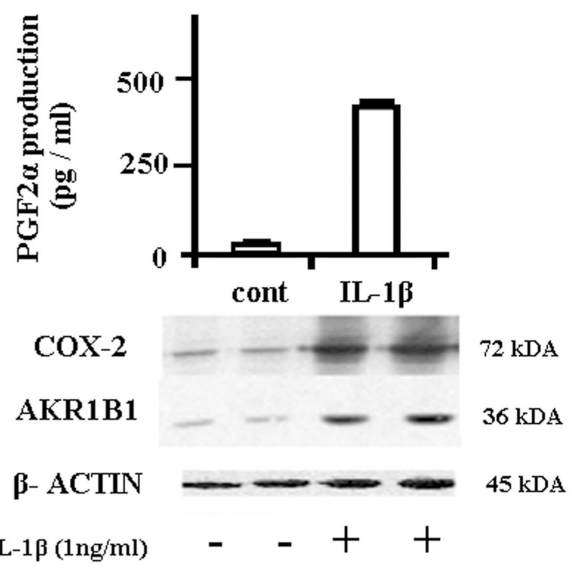

D

\section{Human Umbilical Endothelial cells (HUVEC)}

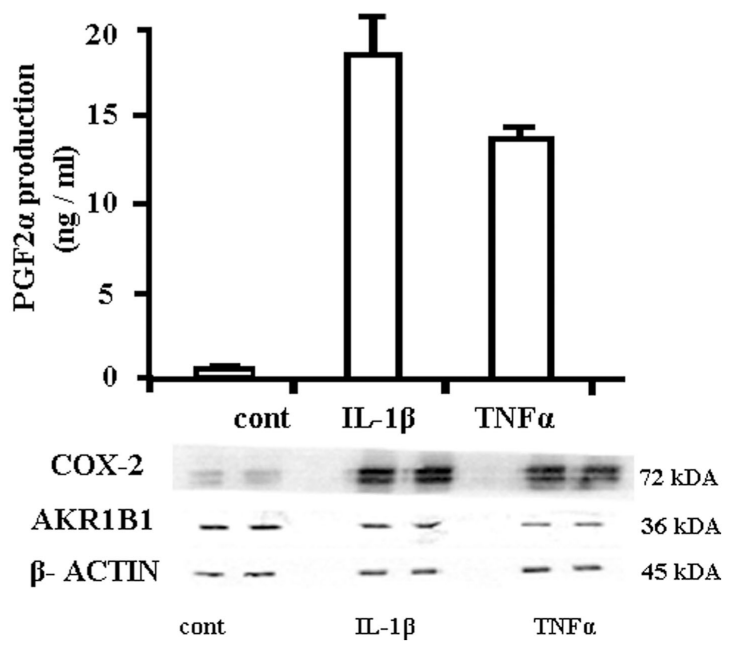

PGF2 $\alpha$ by EIA and protein from attached cells recovered for Western blot analysis of COX-2 and AKR1B1. (A) Prostatic smooth muscle cells, (B) human artery umbilical smooth muscle cells (HUASMC), (C) human cardiomyocytes, and (D) Human Umbilical Endothelial cells (HUVEC). whereas for Northern blots analysis (described above), cells were in 6-well plates. At the end of the treatment period, the culture medium was recovered and stored at $-20^{\circ} \mathrm{C}$ until evaluation of PGF $2 \alpha$ or PGE2 production by EIA whereas protein and RNA were extracted directly from cell monolayer at the bottom of 24-well and 6-well plates, respectively.

\section{ENDOMETRIAL EXPLANTS CULTURE}

Endometrial tissue was obtained either from biopsies collected with an endometrial curette (Pipelle) and obtained from women aged between 25 and 50 years. Informed consent for donation of anonymous endometrial samples was obtained before tissue collection. The research protocol was approved by the Ethics Committee on Human Research of Centre Hospitalier Universitaire de Québec. Endometrial explants were prepared from fresh biopsies as described previously (Bresson et al., 2011). Endometrial explants were stimulated or not with IL$1 \beta$ in the presence or absence of the aldose reductase inhibitor ponalrestat $(100 \mu \mathrm{M})$ under normal $(5 \mathrm{mM})$ or high glucose (25 mM) for $24 \mathrm{~h}$. 

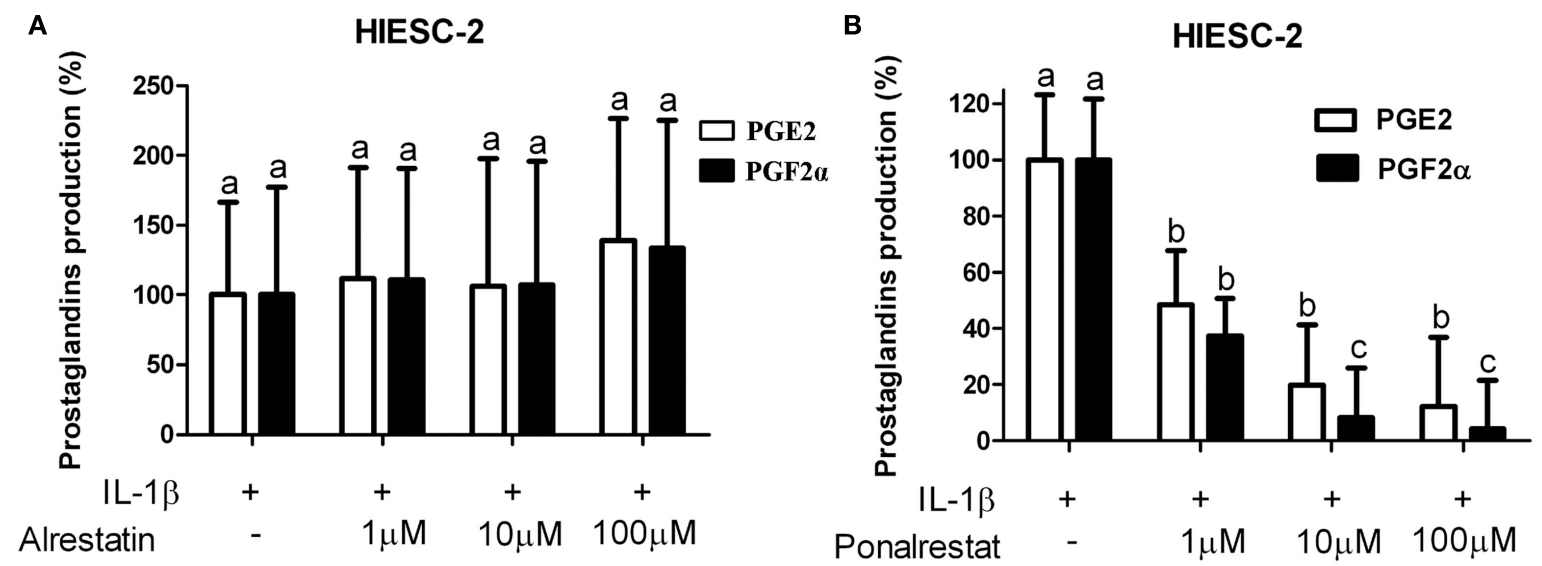

C

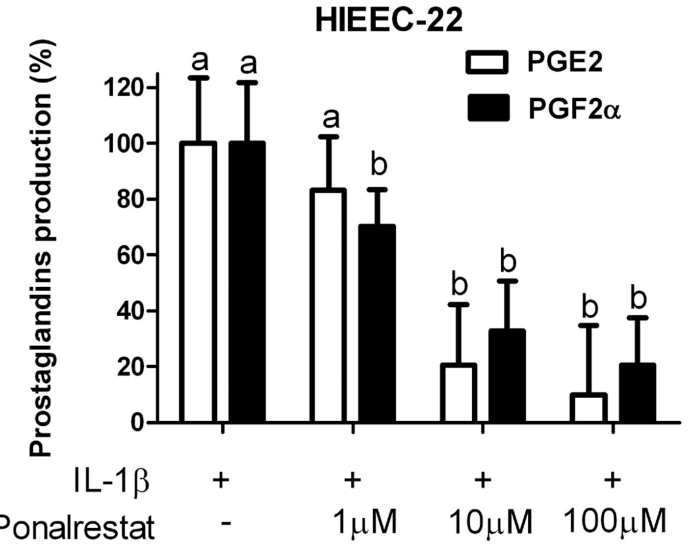

FIGURE 6 | Influence of different aldose reductase inhibitors on PGF2 $\alpha$ and PGE2 production in human and bovine endometrial cells. Human endometrial stromal $[\operatorname{HIESC}-2(\mathbf{A}, \mathbf{B})]$ and human [HIEEC-22 (C)] or bovine epithelial [bEEL (D)] cells were grown to confluence and treated with $1 \mathrm{ng} / \mathrm{ml} \mathrm{IL-1 \beta}$ (A-C) or $10 \mu \mathrm{M}$ arachidonic
D

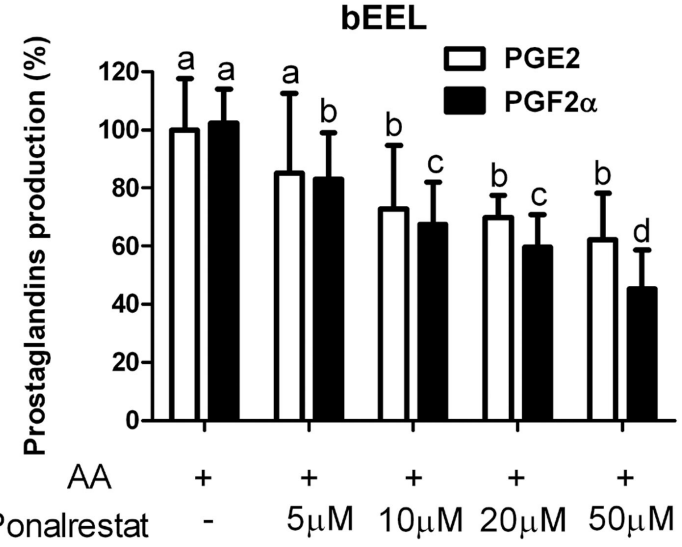

\section{MEASUREMENT OF SORBITOL}

We have developed a LC/MS/MS procedure for quantitative measurement of sorbitol generated in briefly, the culture medium was removed for estimation of PGE2 and PGF2 $\alpha$ and sorbitol was extracted from explants by mixing with lysis buffer $(200 \mu \mathrm{l})$, methanol $(600 \mu \mathrm{l})$, chloroform $(200 \mu \mathrm{l})$, and water $(500 \mu \mathrm{l})$. The mixture was centrifuged for $5 \mathrm{~min}$ at room temperature and $100 \mu \mathrm{l}$ of the upper phase was evaporated with a turbo-vap at $45^{\circ} \mathrm{C}$ for $30 \mathrm{~min}$. The pellet was resuspended with $200 \mu \mathrm{l}$ of Pyridine $10 \%$ : anhydride acetic acid $10 \%$ in acetonitrile and brought at $70^{\circ} \mathrm{C}$ for $45 \mathrm{~min}$. After drying samples were diluted in $100 \mu \mathrm{l}$ methanol/water (1:1) containing $5 \mathrm{mM}$ ammonium acetate. The samples were spiked with Sorbitol-d8 (Omicron Biochemicals Inc., IN, USA) also used for establishment of a standard curve and analyzed on an Applied Biosystems API-5000 LC/MS/MS. The procedure was optimized to minimize interference with sugars and alcohols such as glucose, fructose, galactose, myoinositol, and galactitol.

\section{PGE2 AND PGF2 $\alpha$ EIA}

PGE2 and PGF2 $\alpha$ were assayed by competitive EIA using acetylcholinesterase-linked PG tracers (Cayman, Ann Arbor, MI, USA) as described previously (Asselin et al., 1996).

\section{STATISTICAL ANALYSIS}

Data were analyzed by One or Two way ANOVA with Bonferroni as post hoc test with 95\% confidence intervals using GraphPad Prism 5 program. For data with less than three columns a twotailed unpaired $t$ test with 95\% confidence intervals was performed using GraphPad Prism 5 program. Data are presented as the mean \pm SEM. Each experiment was repeated three times unless specified otherwise. Values were considered statistically significant for $P<0.05$.

\section{RESULTS}

While glucose and oxidized lipids are passive stable substrates for AKR1B1, generation of PGF2 $\alpha$ requires the generation of the unstable PGH2 precursor within the producing cell (Figure 1). Figure 2 illustrates that upon stimulation by IL-1 $\beta$, the rate limiting enzymes cPLA2 releasing AA from membranes phospholipids, COX-2 generating the $\mathrm{PGH} 2$ precursor and AKR1B1 are all increased in both endometrial stromal (A) and epithelial (B) cells. The production of PGF $2 \alpha$ is also increased following IL-1 $\beta$ stimulation, a response blocked by the COX-2 selective inhibitor NS-398 (C and D). As was found previously (Pelletier et al., 1999; Bresson et al., 2011), AKR1C3 is present only in epithelial cells 


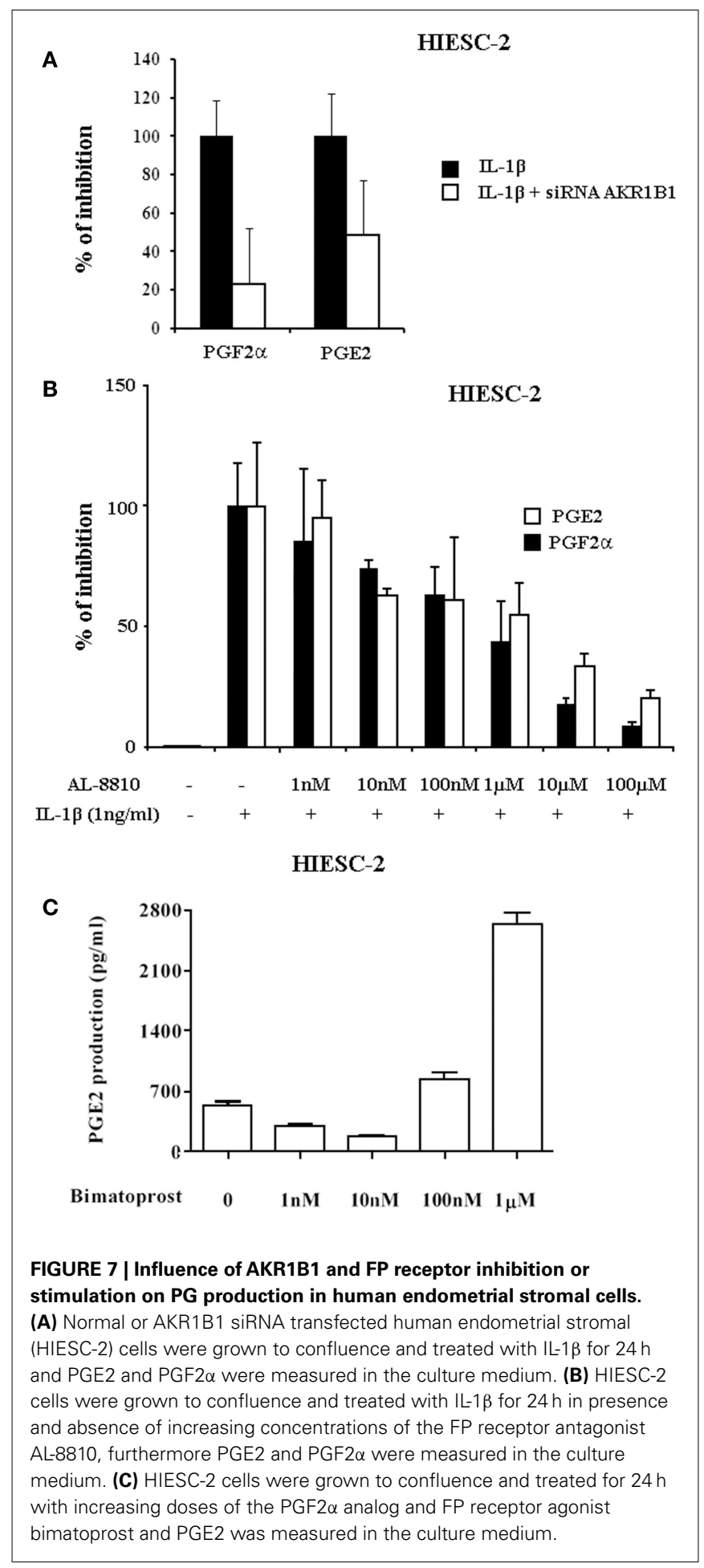

and is not induced by IL- $1 \beta$ suggesting minimal contribution to PGF2 $\alpha$ production under these conditions.

The time course of PG biosynthetic enzymes activation following IL- $1 \beta$ stimulation was investigated at the mRNA level and associated with PGF $2 \alpha$ release (Figure 3). Note that there is basal expression of AKR1B1 gene under non-stimulated conditions and that there is serial transcription of biosynthetic enzyme genes with AKR1B1 preceding COX-2 preceding mPGES-1. Accordingly, PGF2 $\alpha$ release precedes that of PGE2 in both stromal and epithelial cells $(P<0.05)$.

We have cloned the AKR1B1 promoter $(\sim 4.5 \mathrm{~kb})$ and generated eight constructs to identify potential response elements sensitive to IL-1 $\beta$ stimulation (Figure 4 ). IL-1 $\beta$ stimulates the AKR1B1 promoter activity from-583up in both endometrial stromal and epithelial cells (Figure 4A). A MSRR containing two putative antioxidant response elements (ARE) adjacent to TonE and AP1 previously identified for the mouse AKR1B3 (Nishinaka and YabeNishimura, 2005) was also identified for the human AKR1B1 gene at -1710 to -1064 (Figure 4B). The human MSRR region was analyzed in a vector containing a minimal promoter SV40 to identify putative cis-elements of the AKR1B1 gene promoter activity involved in IL- $1 \beta$ response (Figure 4C). The AREs ARE1 and ARE2 appear particularly efficient to confer IL- $1 \beta$ response and may explain the quick activation of AKR1B1 and PGF2 $\alpha$ production observed in Figure 3.

The PGF synthase activity of AKR1B1 and its stimulation by IL-1 $\beta$ and TNF $\alpha$ was investigated in cultured cells isolated from different human tissues (Figure 5). In addition to endometrial cells where we made our initial discovery, we have found that IL$1 \beta$ and to a lesser extent TNF $\alpha$ stimulated AKR1B1, COX-2, and PGF2 $\alpha$ production in prostatic smooth muscle cells (A), arterial smooth muscle cells (B), cardiomyocytes (C), and umbilical endothelial cells (HUVEC D). In the last two models, the observed increase in PGF2 $\alpha$ production appeared to result from increased COX-2 expression coupled with already high preexisting levels of AKR1B1.

We have compared the inhibition potential of three aldose reductase inhibitors; alrestatin, EBPC (not shown) and ponalrestat on human endometrial cells and tested the latter on bovine endometrial epithelial cells (Figure 6). Alrestatin did not have any effect on PGF2 $\alpha$ production (Figure 6A). EBPC inhibited PGF2 $\alpha$ production with an apparent EC50 around $10 \mu \mathrm{M}$ (not shown) whereas ponalrestat was the most potent with an EC50 of $1 \mu \mathrm{M}$ (Figure 6B). Ponalrestat also inhibited PGF2 $\alpha$ in human (Figure 6C) and bovine (Figure 6D) endometrial epithelial cells albeit with reduced efficiency exhibiting an EC50 of $50 \mu \mathrm{M}$. Interestingly, ARIs not only inhibited PGF2 $\alpha$ but also PGE2 in all cell models.

The potential non-selective inhibition of several components of PG biosynthesis by ARIs was investigated further (Figure 7). When AKR1B1 expression was knocked down by siRNA, similar observation of concurrent inhibition of PGF2 $\alpha$ and PGE2 was observed (Figure 7A) suggesting potential interactions between the two biosynthetic pathways. The possibility that AKR1B1 could exert positive regulation of PGE2 production through PGF2 $\alpha$ and its FP receptor was tested (Figure 7B). Interestingly, when AKR1B1 and PGF $2 \alpha$ production are stimulated with IL-1 $\beta, P G F 2 \alpha$, and the concomitant increase of PGE2 is reduced in presence of the FP receptor antagonist $\mathrm{AL}-8810$ suggesting that $\mathrm{PGF} 2 \alpha$ was able to stimulate its own and PGE2 production. The latter hypothesis was tested using the PGF2 $\alpha$ analog bimatoprost which stimulated PGE2 release in a dose dependent manner (Figure 7C).

Finally, the relative affinity and potential competition between the PGFS and polyol pathway was tested under close to in vivo 


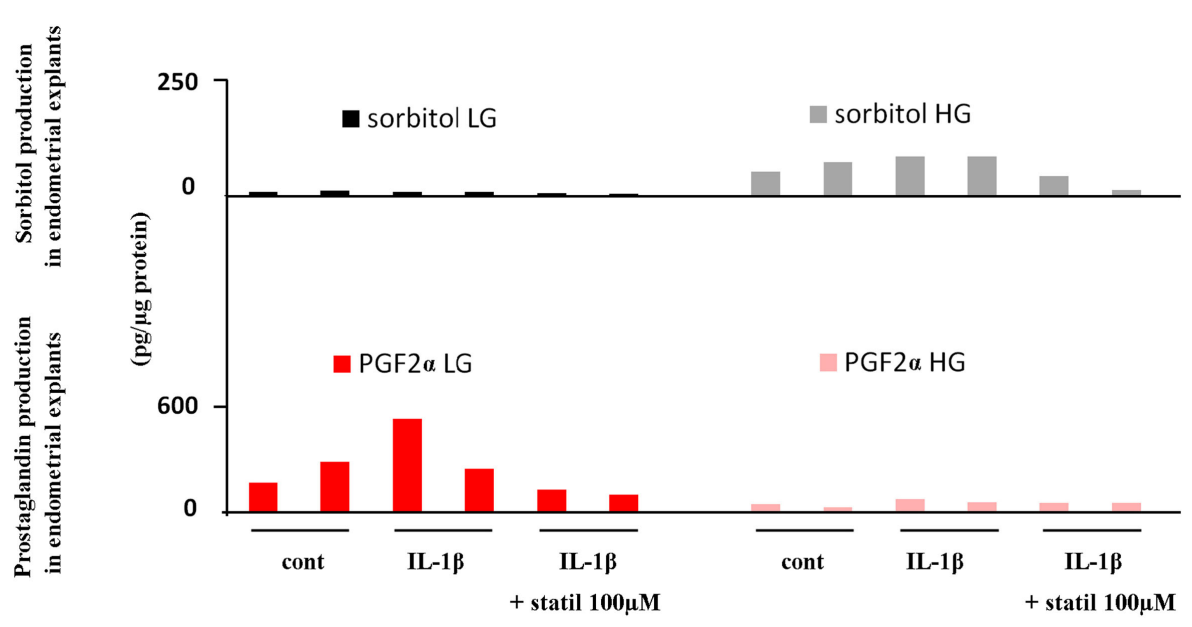

FIGURE 8 | Influence of glucose concentration on the relative production of sorbitol and PGF2 $\alpha$ in fresh explants from human endometrium. Endometrial explants were prepared from fresh endometrial biopsies, cultured for $24 \mathrm{~h}$, and stimulated with IL-1 $\beta$ (10 ng/ml) in presence or absence of Statil (ponalrestat, $100 \mu \mathrm{M}$ ) under normal (LG) $5 \mathrm{mg} / \mathrm{ml}$ or High (HG) $25 \mathrm{mg} / \mathrm{ml}$ glucose concentrations. PGF2 $\alpha$ production was measured by EIA. Results from two different experiments are illustrated. conditions (Figure 8). Fresh endometrial explants were treated with IL-1 $\beta$ in presence and absence of ponalrestat under normal and high glucose conditions. Interestingly, IL-1 $\beta$ previously demonstrated to increase AKR1B1 expression increased PGF2 $\alpha$ or sorbitol production depending on normal or high glucose conditions respectively. This demonstrates that PGF2 $\alpha$ and sorbitol are formed competitively depending on the relative availability of AKR1B1 substrates.

\section{DISCUSSION}

Prostaglandins are important regulators of female reproductive function and contribute to gynecological disorders. Normal menstruation depend on an equilibrium between vasoconstrictors such as PGF2 $\alpha$ (Lockwood and Schatz, 1996; Sales and Jabbour, 2003a) and vasodilators such as PGE2 or nitric oxide (NO) (Tschugguel et al., 1999). Excessive production of contracting prostaglandins create an ischemia-reperfusion response causing painful menstruation or dysmenorrhea (Okazaki et al., 2005) whereas increased vasodilatation leads to abundant menstrual bleeding (Sales and Jabbour, 2003b). NSAIDs represent the most important and widely used drugs on the market and they are all efficient to treat menstrual disorders at some level. However these drugs act at an early step of biosynthesis common to all PGs and not only the isotype responsible for the pathological response (Figure 9). Because of its notorious role on inflammation and pain, the biosynthetic pathway leading to PGE2 has been studied extensively, but that of PGF $2 \alpha$ is poorly documented. The data presented in this manuscript address the conditions regulating the newly identified PGFS activity of AKR1B1. In the human endometrium, it has been reported that production of PGF $2 \alpha$ is higher in late secretory and menstrual periods of the menstrual cycle (Downie et al., 1974). Accordingly, both AKR1B1 and AKR1C3 enzymes are present in the endometrium throughout the menstrual cycle. By contrast with AKR1B1expressed in both stromal and glandular epithelial cells and modulated in association with endometrial PGF2 $\alpha$ production, AKR1C3 expression is constant and completely absent in stromal cells as was reported previously (Pelletier et al., 1999; Zakharov et al., 2010). The absence of the only currently accepted human PGFS AKR1C3 in stromal cells was surprising because we and others have shown that human endometrial stromal cells produce high levels of PGF2 $\alpha$ (Huang et al., 1998; Chapdelaine et al., 2006; Kang et al., 2006). Because of a similar finding in the bovine endometrium and our identification of AKR1B5 as a functional PGFS in that system (Madore et al., 2003), we hypothesized that the human AKR1B1, could also express PGFS activity in the human endometrium. Our initial studies showing the association between AKR1B1 expression and PGF $2 \alpha$ production was confirmed unequivocally in the human endometrium using gain and loss of function approaches (Bresson et al., 2011). The PGF synthase activity of AKR1B1 and other members of this family is now acknowledged by leaders in the field of prostaglandin synthases (Nagata et al., 2011; Smith et al., 2011; Watanabe, 2011).

In the present study we highlight the necessary co-activation of genes of the PG biosynthesis pathway to provide the PGH2 precursor substrate to AKR1B1 in order to generate PGF2 $\alpha$. This is in clear contrast with detoxification or aldose reductase activities of AKR1B1 for which substrates are provided by extracellular sources (glucose) or as byproducts of intracellular reactions (oxidized lipids). Endometrial cells express constitutively GLUT2 and GLUT3 and do not require insulin for glucose entry, as such; the endometrium belongs to the category of tissues most adversely affected by poorly controlled glucose levels occurring during insulin resistance or diabetes. Figures 2 and $\mathbf{3}$ illustrate that genes and proteins of the biosynthetic pathway are increased in a time and dose dependent manner to explain increased PGF $2 \alpha$ production following IL- $1 \beta$ stimulation.

In Figure $\mathbf{3}$ and then in Figures $\mathbf{6}$ and $\mathbf{7}$ we observe that PGE2 production closely follows that of PGF $2 \alpha$ under both stimulatory and inhibitory conditions. We first considered these results 


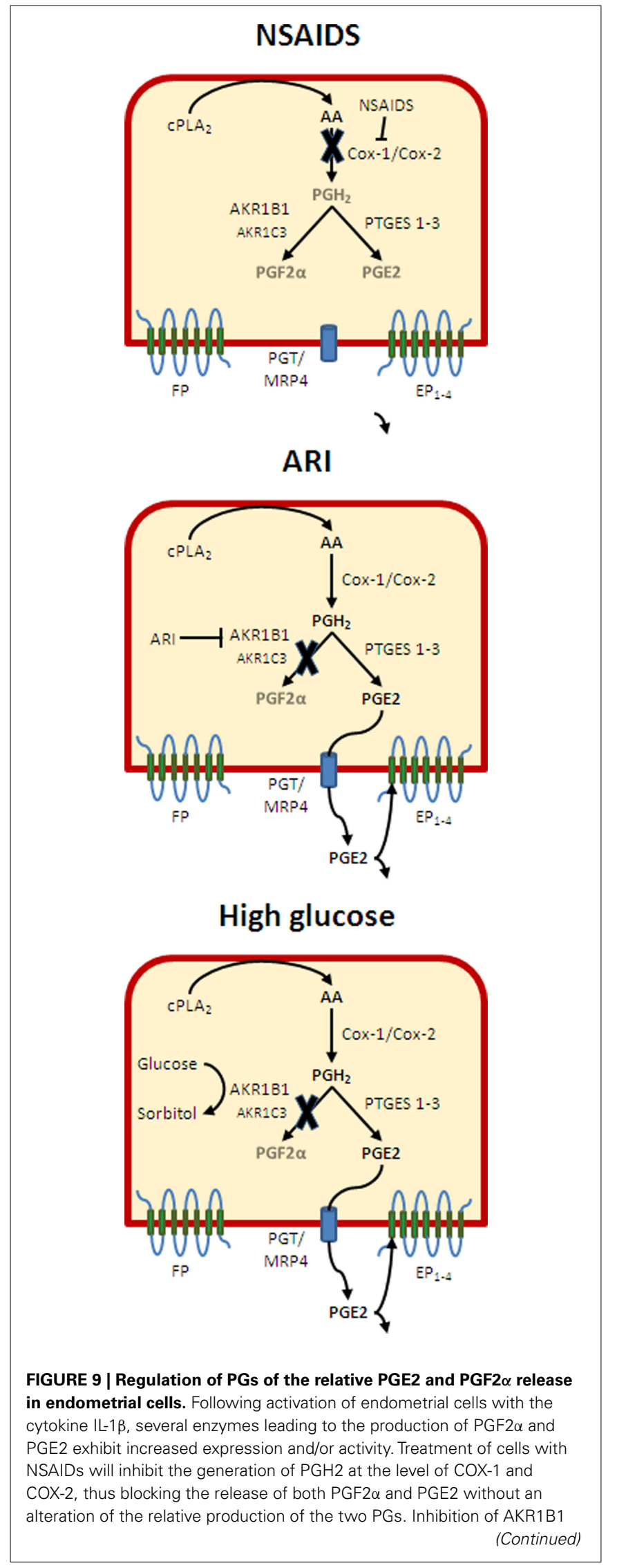

\section{FIGURE 9 | Continued}

activity with ARIs will inhibit preferentially PGF2 $\alpha$ release thus creating an imbalance in favor of PGE2. However, decreased stimulation of the FP receptor should down-regulate the production of PGE2. In presence of high glucose concentration, the stimulation of AKR1B1 may be exacerbated, but glucose should inhibit competitively PGF2 $\alpha$ release in which case reduced FP stimulation should also reduce PGE2 production. However, when glucose concentration falls back to normal, high AKR1B1 levels would favor PGF2 $\alpha$ release and ischemic responses until PGE2 is able to compensate through EP2 and bring back a silent condition where the balance between PGF2 $\alpha$ and PGE2 is re-established.

as artifact and resulting from defective experimental design. However, when we observed that inhibition of FP receptor prevented the increase in PGE2 and that FP receptor stimulation alone was sufficient to stimulate PGE2 production, we proposed that there was a positive feedback loop between PGF2 $\alpha$ release and production of PGE2. A link between FP activation and increased PG production could have been anticipated from previous observations in a human endometrial model (Jabbour et al., 2005; Sales et al., 2008) and from our own observations in bovine endometrial cells (Krishnaswamy et al., 2010) given that FP and the oxytocin receptor (OT) share the same signal transduction systems. However, this is the first evidence of a specific link between FP activation and PGE2 production within a homogeneous cell system with potential physiological and pathological relevance. If we hypothesize that PGE2 acting on EP2 receptors and PGF2 $\alpha$ acting through FP work as a dyad with opposite actions in the reproductive system, just like the thromboxane/prostacyclin dyad in the vascular system, then the interactions between the two systems are not only probable but also necessary.

Prostaglandins work like a micro endocrine system sensing altered conditions and reestablish locally, optimal conditions for tightly regulated events such as ovulation or recognition of pregnancy in the reproductive system or hemostasis in the vascular system. In this respect, PGF2 $\alpha$ exhibits vasoconstrictive and prothrombotic responses comparable to thromboxane with the additional feature that the PGF2 $\alpha$ molecule is chemically stable and remains active until catabolism by prostaglandin dehydrogenase, usually through a single passage in the lung. By contrast PGE2/EP2 trigger a vasodilator response with anti thrombotic action similar to prostacyclin but again PGE2 is much more stable than PGI2. Thus it is important to tightly regulate the relative production and release of PGF2 $\alpha$ and PGE2 and in this respect; our identification of a feedback loop between PGF2 $\alpha$ and PGE2 within endometrial cells has important implications for the observed complications associated with over-expression of AKR1B1. We have initiated the characterization of the AKR1B1 promoter and identified a MSRR containing two putative AREs adjacent to TonE and AP1. The AREs ARE1 and ARE2 appear to be involved in IL-1 $\beta$ response, which supports the local sensing functions of PGs to which AKR1B1 is now a contributing component. The MSRR portion of the AKR1B1 promoter will have to be investigated further under IL-1 $\beta$ stimulation to identify the trans-factors associated with the production of PGF2 $\alpha$. Because of its reported interaction with AREs, NRF2 also known as Nuclear factor (erythroid-derived 2)-like 2 (NFE2L2) is a likely candidate to link increased PGF2 $\alpha$ release 
under inflammatory conditions (Nishinaka and Yabe-Nishimura, 2005).

Clinical and pathological implications: Prostaglandins are important regulators of female reproductive functions. In this respect, gene inactivation studies in the mouse have shown that COX-2 and EP2 null mice share similar phenotypes where ovulation and implantation are impaired (Lim et al., 1997; Kennedy et al., 1999). The PGF2 $\alpha / F P$ system is much less documented than that of PGE2, but the group of Jabbour in Edinburg has documented its involvement in endometrial pathologies including menstrual disorders and endometrial cancer (Milne and Jabbour, 2003; Jabbour and Sales, 2004; Sales et al., 2004; Jabbour et al., 2005, 2006; Abera et al., 2010; Catalano et al., 2011) while we (Breuiller-Fouche et al., 2010; Phillips et al., 2011) and others (Olson and Ammann, 2007) associate it with premature delivery. With that in mind, it is likely that AKR1B1 contribute to these pathologies and conversely conditions where AKR1B1 is affected such as diabetes and metabolic syndrome may exhibit a specific prognosis pattern in affected women. In addition, we claim that the female reproductive system constitutes a powerful model to understand the contribution of PGs to physio-pathological conditions in other systems. This is supported by Figure $\mathbf{5}$ showing the relation between AKR1B1 and PG biosynthetic enzymes in response to IL-1 $\beta$ and their association with PGF2 $\alpha$ production in smooth muscles, cardiomyocytes, and endothelial cells. This is all the more important as AKR1B1 known to be highly responsive to diverse physiologic and pathologic conditions and its multiple substrate processing ability combine to create complex combinations well illustrated in Figure 8. For instance, PGF2 $\alpha$ has been associated with cardiac hypertrophy (Lai et al., 1996) and a new hamster AKR1B was identified and proposed to contribute to cardiomyopathy through PGF2 $\alpha$ release (Sakamoto and Sugamoto, 2011). Moreover, knowing that high glucose induce AKR1B1 expression

\section{REFERENCES}

Abera, A. B., Sales, K. J., Catalano, R. D., Katz, A. A., and Jabbour, H. N. (2010). EP2 receptor mediated cAMP release is augmented by PGF 2 alpha activation of the FP receptor via the calciumcalmodulin pathway. Cell. Signal. 22, 71-79.

Alexiou, P., Pegklidou, K., Chatzopoulou, M., Nicolaou, I., and Demopoulos, V. J. (2009). Aldose reductase enzyme and its implication to major health problems of the 21(st) century. Curr. Med. Chem. 16, 734-752.

Asselin, E., Goff, A. K., Bergeron, H., and Fortier, M. A. (1996). Influence of sex steroids on the production of prostaglandins F2 alpha and E2 and response to oxytocin in cultured epithelial and stromal cells of the bovine endometrium. Biol. Reprod. 54, 371-379.

Baron, J. A., Sandler, R. S., Bresalier, R. S., Lanas, A., Morton, D. G., Riddell, R., Iverson, E. R., and Demets, D. L. of the APPROVe trial. Lancet 372,

we see that as long as glucose levels remain high, there will be little increase in PGF2 $\alpha$ release, but when glucose goes down, the high levels of AKR1B1 will generate increased production of PGF2 $\alpha$ (Figure 9). In turn, high PGF2 $\alpha$ will trigger pro-ischemic responses (Yuhki et al., 2010) that fortunately will be compensated by the feedback loop release of PGE2 exerting opposite action thus bringing back homeostasis (Mandal et al., 2005). Normal tension results from the action of EP2 opposing FP receptors in the vascular system, but adjacent tissues also express other EP receptors responsible for inflammation and pain. Therefore the relative silent condition resulting from PGE2 compensation of overproduction of PGF2 $\alpha$ by AKR1B1 will likely generate pain or hyperalgesia increasing the probability to take NSAIDs. Not that far ago, the best pain killer on the market with minimal gastrointestinal toxicity was rofecoxib (Vioxx), the most powerful medication to date eradicating pain by reducing mPGES- 1 generated PGE2. If someone taking Vioxx was under the silent (increased AKR1B1) condition, then the compensatory PGE2/EP2 would not be available to counteract the ischemic response to PGF2 $\alpha$ thus increasing the risks of heart failure. Interestingly, even after adjustment of risk factors, reexamination of Vioxx events (Baron et al., 2008) reveal that people suffering from type two diabetes were eight times more at risk to die from Vioxx than non-diabetics. By contrast people taking both Vioxx and Aspirin, thus blocking the AKR1B1 generated PGF2 $\alpha$ were protected. Therefore, it is worth investigating if and how AKR1B1 potentially contributed to the failure of Vioxx.

In conclusion, the ability of AKR1B1 to release PGF2 $\alpha$ brings a new angle to look at mechanisms responsible for pathophysiologic conditions in the woman reproductive and other systems especially in association with diabetes.

\section{ACKNOWLEDGEMENT}

Supported by grants from CIHR.

menstrual cycle. Mol. Hum. Reprod. 17, 182-192.

ciated with 1756-1764.

Bresson, E., Boucher-Kovalik, S., Chapdelaine, P., Madore, E., Harvey, N., Laberge, P. Y., Leboeuf, M., and Fortier, M. A. (2011). The human aldose reductase AKR1B1 qualifies as the primary prostaglandin F synthase in the endometrium. J. Clin. Endocrinol. Metab. 96, 210-219.

Breuiller-Fouche, M., Leroy, M. J., Dubois, O., Reinaud, P., Chissey, A., Qi, H., Germain, G., Fortier, M. A., and Charpigny, G. (2010). Differential expression of the enzymatic system controlling synthesis, metabolism, and transport of PGF2 alpha in human fetal membranes. Biol. Reprod. 83, 155-162.

Catalano, R. D., Wilson, M. R., Boddy, S. C., and Jabbour, H. N. (2011). Comprehensive expression analysis of prostanoid enzymes and receptors in the human endometrium across the
Chapdelaine, P., Kang, J., BoucherKovalik, S., Caron, N., Tremblay, J. P., and Fortier, M. A. (2006). Decidualization and maintenance of a functional prostaglandin system in human endometrial cell lines following transformation with SV40 large $\mathrm{T}$ antigen. Mol. Hum. Reprod. 12, 309-319.

Del Corso, A., Cappiello, M., and Mura, U. (2008). From a dull enzyme to something else: facts and perspectives regarding aldose reductase. Curr. Med. Chem. 15, 1452-1461.

Downie, J., Poyser, N. L., and Wunderlich, M. (1974). Levels of prostaglandins in human endometrium during the normal menstrual cycle. J. Physiol. (Lond.) 236, 465-472.

Huang, J. C., Liu, D. Y., Yadollahi, S., Wu, K. K., and Dawood, M. Y. (1998). Interleukin-1 beta induces cyclooxygenase- 2 gene expression in cultured endometrial stromal cells. J. Clin. Endocrinol. Metab. 83, 538-541.

Jabbour, H. N., and Sales, K. J. (2004). Prostaglandin receptor signalling and function in human endometrial pathology. Trends Endocrinol. Metab. 15, 398-404.

Jabbour, H. N., Sales, K. J., Boddy, S. C., Anderson, R. A., and Williams, A. R. (2005). A positive feedback loop that regulates cyclooxygenase-2 expression and prostaglandin F2alpha synthesis via the F-series-prostanoid receptor and extracellular signalregulated kinase 1/2 signaling pathway. Endocrinology 146, 4657-4664.

Jabbour, H. N., Sales, K. J., Smith, O. P., Battersby, S., and Boddy, S. C. (2006). Prostaglandin receptors are mediators of vascular function in endometrial pathologies. Mol. Cell. Endocrinol. 252, 191-200.

Jin, Y., and Penning, T. M. (2007). Aldo-keto reductases and bioactivation/detoxication. Annu. Rev. Pharmacol. Toxicol. 47, 263-292. 
Kabututu, Z., Manin, M., Pointud, J. C., Maruyama, T., Nagata, N., Lambert, S., Lefrancois-Martinez, A. M., Martinez, A., and Urade, Y. (2009). Prostaglandin F2alpha synthase activities of aldo-keto reductase 1B1, 1B3 and 1B7. J. Biochem. 145, 161-168.

Kang, J., Akoum, A., Chapdelaine, P., Laberge, P., Poubelle, P. E., and Fortier, M. A. (2004). Independent regulation of prostaglandins and monocyte chemoattractant protein1 by interleukin-1beta and hCG in human endometrial cells. Hum. Reprod. 19, 2465-2473.

Kang, J., Chapdelaine, P., Laberge, P. Y., and Fortier, M. A. (2006). Functional characterization of prostaglandin transporter and terminal prostaglandin synthases during decidualization of human endometrial stromal cells. Hum. Reprod. 21, 592-599.

Kennedy, C. R., Zhang, Y., Brandon, S., Guan, Y., Coffee, K., Funk, C. D., Magnuson, M. A., Oates, J. A., Breyer, M. D., and Breyer, R. M. (1999). Salt-sensitive hypertension and reduced fertility in mice lacking the prostaglandin EP2 receptor. Nat. Med. 5, 217-220.

Komoto, J., Yamada, T., Watanabe, K., Woodward, D. F., and Takusagawa, F. (2006). Prostaglandin F2alpha formation from prostaglandin $\mathrm{H} 2$ by prostaglandin $\mathrm{F}$ synthase (PGFS): crystal structure of PGFS containing bimatoprost. Biochemistry 45, 1987-1996.

Krishnaswamy, N., Danyod, G., Chapdelaine, P., and Fortier, M. A. (2009). Oxytocin receptor down-regulation is not necessary for reducing oxytocin-induced prostaglandin $\mathrm{F}$ (2alpha) accumulation by interferon-tau in a bovine endometrial epithelial cell line. Endocrinology 150, 897-905.

Krishnaswamy, N., Lacroix-Pepin, N., Chapdelaine, P., Taniguchi, H., Kauffenstein, G., Chakravarti, A., Danyod, G., and Fortier, M. A. (2010). Epidermal growth factor receptor is an obligatory intermediate for oxytocin-induced cyclooxygenase 2 expression and prostaglandin F2 alpha production in bovine endometrial epithelial cells. Endocrinology 151, 1367-1374.

Lacroix-Pepin, N., Danyod, G., Krishnaswamy, N., Mondal, S., Rong, P. M., Chapdelaine, P., and Fortier, M. A. (2011). The multidrug resistance-associated protein 4 (MRP4) appears as a functional carrier of prostaglandins regulated by oxytocin in the bovine endometrium. Endocrinology 152, 4993-5004.

Lai, J., Jin, H., Yang, R., Winer, J., Li, W., Yen, R., King, K. L., Zeigler, F., Ko, A., Cheng, J., Bunting, S., and Paoni, N. F. (1996). Prostaglandin F2 alpha induces cardiac myocyte hypertrophy in vitro and cardiac growth in vivo. Am. J. Physiol. 271, H2197-H2208.

Lim, H., Paria, B. C., Das, S. K., Dinchuk, J. E., Langenbach, R., Trzaskos, J. M., and Dey, S. K. (1997). Multiple female reproductive failures in cyclooxygenase 2-deficient mice. Cell 91, 197-208.

Lockwood, C. J., and Schatz, F. (1996). A biological model for the regulation of peri-implantational hemostasis and menstruation. J. Soc. Gynecol. Investig. 3, 159-165.

Madore, E., Harvey, N., Parent, J., Chapdelaine, P., Arosh, J. A., and Fortier, M. A. (2003). An aldose reductase with 20 alphahydroxysteroid dehydrogenase activity is most likely the enzyme responsible for the production of prostaglandin $\mathrm{f} 2$ alpha in the bovine endometrium. J. Biol. Chem. 278, 11205-11212.

Mandal, A. K., Zhang, Z., Kim, S. J., Tsai, P. C., and Mukherjee, A. B. (2005). Yin-yang: balancing act of prostaglandins with opposing functions to regulate inflammation. $J$. Immunol. 175, 6271-6273.

Milne, S. A., and Jabbour, H. N. (2003). Prostaglandin (PG) F(2alpha) receptor expression and signaling in human endometrium: role of PGF(2alpha) in epithelial cell proliferation. J. Clin. Endocrinol. Metab. 88, 1825-1832.

Nagata, N., Kusakari, Y., Fukunishi, Y., Inoue, T., and Urade, Y. (2011). Catalytic mechanism of the primary human prostaglandin F2alpha synthase, aldo-keto reductase 1B1 prostaglandin D2 synthase activity in the absence of $\operatorname{NADP}(\mathrm{H})$. FEBS J. 278, 1288-1298.

Narumiya, S., and FitzGerald, G. A. (2001). Genetic and pharmacological analysis of prostanoid receptor function. J. Clin. Invest. 108, 25-30.

Nishinaka, T., and Yabe-Nishimura, C. (2005). Transcription factor $\mathrm{Nrf} 2$ regulates promoter activity of mouse aldose reductase (AKR1B3) gene. J. Pharmacol. Sci. 97, 43-51.

Okazaki, M., Matsuyama, T., Kohno, T., Shindo, H., Koji, T., Morimoto, Y., and Ishimaru, T. (2005). Induction of epithelial cell apoptosis in the uterus by a mouse uterine ischemiareperfusion model: possible involvement of tumor necrosis factor-alpha. Biol. Reprod. 72, 1282-1288.

Olson, D. M., and Ammann, C. (2007). Role of the prostaglandins in labour and prostaglandin receptor inhibitors in the prevention of preterm labour. Front. Biosci. 12, 1329-1343.

Park, J. Y., Pillinger, M. H., and Abramson, S. B. (2006). Prostaglandin E2 synthesis and secretion: the role of PGE2 synthases. Clin. Immunol. 119 , 229-240.

Pelletier, G., Luu-the, V., Tetu, B. and Labrie, F. (1999). Immunocytochemical localization of type 5 17beta-hydroxysteroid dehydrogenase in human reproductive tissues. J. Histochem. Cytochem. 47, 731-738.

Phillips, R. J., Al-Zamil, H., Hunt, L. P., Fortier, M. A., and Lopez Bernal, A. (2011). Genes for prostaglandin synthesis, transport and inactivation are differentially expressed in human uterine tissues, and the prostaglandin $\mathrm{F}$ synthase AKR1B1 is induced in myometrial cells by inflammatory cytokines. Mol. Hum. Reprod. 17, 1-13.

Sakamoto, A., and Sugamoto, Y. (2011). Identification of a novel aldose reductase-like gene upregulated in the failing heart of cardiomyopathic hamster. Mol. Cell. Biochem. 353, 275-281.

Sales, K. J., Grant, V., and Jabbour, H. N. (2008). Prostaglandin E2 and F2alpha activate the FP receptor and up-regulate cyclooxygenase-2 expression via the cyclic AMP response element. Mol. Cell. Endocrinol. 285, 51-61.

Sales, K. J., and Jabbour, H. N. (2003a). Cyclooxygenase enzymes and prostaglandins in pathology of the endometrium. Reproduction 126 559-567.

Sales, K. J., and Jabbour, H. N. (2003b). Cyclooxygenase enzymes and prostaglandins in reproductive tract physiology and pathology. Prostaglandins Other Lipid Mediat. 71, 97-117.

Sales, K. J., Milne, S. A., Williams, A. R. Anderson, R. A., and Jabbour, H. N. (2004). Expression, localization, and signaling of prostaglandin F2 alpha receptor in human endometrial adenocarcinoma: regulation of proliferation by activation of the epidermal growth factor receptor and mitogenactivated protein kinase signaling pathways. J. Clin. Endocrinol. Metab. 89, 986-993.
Smith, S. K., and Kelly, R. W. (1988). The release of PGF2 alpha and PGE2 from separated cells of human endometrium and decidua. Prostaglandins Leukot. Essent. Fatty Acids 33, 91-96.

Smith, W. L., Garavito, R. M., and Dewitt, D. L. (1996). Prostaglandin endoperoxide $\mathrm{H}$ synthases (cyclooxygenases)-1 and -2 . J. Biol. Chem. 271, 33157-33160.

Smith, W. L., Urade, Y., and Jakobsson, P. J. (2011). Enzymes of the cyclooxygenase pathways of prostanoid biosynthesis. Chem. Rev. 111, 5821-5865.

Srivastava, S. K., Ramana, K. V., and Bhatnagar, A. (2005). Role of aldose reductase and oxidative damage in diabetes and the consequent potential for therapeutic options. Endocr. Rev. 26, 380-392.

Suzuki-Yamamoto, T., Nishizawa, M., Fukui, M., Okuda-Ashitaka, E., Nakajima, T., Ito, S., and Watanabe, K. (1999). cDNA cloning, expression and characterization of human prostaglandin F synthase. FEBS Lett. 462, 335-340.

Tschugguel, W., Schneeberger, C., Unfried, G., Brautigam, G., Stonek, F., Wieser, F., Vytiska-Binstorfer, E., Czerwenka, K., Weninger, W., Kaider, A., Bursch, W., Breitschopf, H., and Huber, J. C. (1999). Elevation of inducible nitric oxide synthase activity in human endometrium during menstruation. Biol. Reprod. 60, 297-304.

Watanabe, K. (2002). Prostaglandin F synthase. Prostaglandins Other Lipid Mediat. 69, 401-407.

Watanabe, K. (2011). Recent reports about enzymes related to the synthesis of prostaglandin (PG) $\mathrm{F}$ (2) (PGF(2alpha) and 9alpha, 11beta-PGF(2)). J. Biochem. 150, 593-596.

Wu, K. K., and Liou, J. Y. (2005). Cellular and molecular biology of prostacyclin synthase. Biochem. Biophys. Res. Commun. 338, 45-52.

Yuhki, K., Kashiwagi, H., Kojima, F., Kawabe, J., and Ushikubi, F. (2010). Roles of prostanoids in the pathogenesis of cardiovascular diseases. Int. Angiol. 29, 19-27.

Zakharov, V., Lin, H. K., Azzarello, J., Mcmeekin, S., Moore, K. N., Penning, T. M., and Fung, K. M. (2010). Suppressed expression of type 2 3alpha/type 5 17beta-hydroxysteroid dehydrogenase (AKR1C3) in endometrial hyperplasia and carcinoma. Int. J. Clin. Exp. Pathol. 3, 608-617. 
Zhou, Y., Shaw, N., Li, Y., Zhao, Y., Zhang, R., and Liu, Z. J. (2010). Structure-function analysis of human l-prostaglandin D synthase bound with fatty acid molecules. FASEB J. 24, 4668-4677.

Conflict of Interest Statement: The authors declare that the research was conducted in the absence of any commercial or financial relationships that could be construed as a potential conflict of interest.

Received: 01 March 2012; paper pending published: 09 April 2012; accepted: 02 May 2012; published online: 25 May 2012.

Citation: Bresson E, Lacroix-Pépin N, Boucher-Kovalik S, Chapdelaine $P$ and
Fortier MA (2012) The prostaglandin $F$ synthase activity of the human aldose reductase $A K R 1 B 1$ brings new lenses to look at pathologic conditions. Front. Pharmacol. 3:98. doi: 10.3389/fphar.2012.00098

This article was submitted to Frontiers in Experimental Pharmacology and Drug Discovery, a specialty of Frontiers in Pharmacology.
Copyright (C) 2012 Bresson, LacroixPépin, Boucher-Kovalik, Chapdelaine and Fortier. This is an open-access article distributed under the terms of the Creative Commons Attribution Non Commercial License, which permits non-commercial use, distribution, and reproduction in other forums, provided the original authors and source are credited. 